\title{
Genetic parameters for lamb carcass traits assessed by video image analysis, EUROP classification and in vivo measurements.
}

\author{
Eythór Einarsson ${ }^{1}$, Emma Eythórsdóttir ${ }^{1 *}$, Chris R. Smith ${ }^{2}$, And Jón Vidar Jónmundsson ${ }^{3}$ \\ ${ }^{1}$ The Agricultural University of Iceland, Hvanneyri, 311 Borgarnes, Iceland \\ ${ }^{2}$ Cedar Creek Company Unit 10/11 62 Bishop St.Kelvin Grove, Brisbane, QLD 4059, Australia \\ ${ }^{3}$ The Farmers Association of Iceland, Hagatorgi 1, 107 Reykjavik, Iceland \\ *Email:emma@lbhi.is (corresponding author)
}

\begin{abstract}
The heritability of yield predictions obtained from video image analysis (VIAscan ${ }^{\circledR}$ ) of lamb carcasses $(n=18,680)$ and EUROP classes obtained by abattoir assessors $(n=26,795)$ was estimated, as well as the genetic and phenotypic correlations between VIAscan ${ }^{\circledR}$ traits and in vivo lamb traits $(\mathrm{n}=9,930)$, including ultrasonic measurements, visual conformation score and length of the cannon bone. The main objective of the study was to test the equivalence of EUROP classes obtained by VIAscan ${ }^{\circledR}$ and visual scoring as selection criteria in the breeding work. Genetic correlations between EUROP scores from VIAscan ${ }^{\circledR}$ and from abattoir assessors were 0.94 for conformation and 0.82 for fat score. The heritability of conformation score was 0.32 and 0.35 based on VIAscan ${ }^{\circledR}$ and visual scoring, and 0.29 and 0.31 for the fat score, respectively. Yield predictions as proportions of lean meat of carcass weight from VIAscan ${ }^{\circledR}$ were highly heritable, $\mathrm{h}^{2}$ ranging from 0.39 to 0.63 . Lean meat yield (LMY) estimated as lean weight in major cuts had a direct heritability ranging from 0.17 to 0.21 , maternal heritability ranging from 0.09 to 0.11 and a common environmental $\left(\mathrm{c}^{2}\right)$ effect of 0.22-0.23. Lean meat yield of the whole carcass (LMY_\%) had the highest genetic correlation to visual leg score $(0.44)$ while correlations between lean yield of three carcass parts (LegY_\%, LoinY_\% and ShoulderY_\%) and in vivo measurements were low to moderately high and favourable except for loin yield. The EUROP scores obtained by both methods had similar genetic and phenotypic correlations to in vivo traits where conformation scores were highly correlated to visual scores for legs and shoulders and ultrasonic muscle measurements and fat scores were positively correlated to ultrasonic fat measurements and shoulder scores. It is concluded that VIAscan ${ }^{\circledR}$ can be used as a grading tool for the Icelandic sheep industry and measurements of carcass traits obtained from the system would be useful in the national sheep breeding program.
\end{abstract}

Keywords: Genetic parameters, Video image analysis, lamb carcasses, EUROP classification, lean meat yield, ultrasound measurements.

\section{YFIRLIT}

Erfðastuðlar fyrir skrokkeiginleika lamba moeldum með rafrcenum aðferðum, EUROP flokkun og mati á lifandi lömbum.

Arfgengi vöðvahlutfalls lambaskrokka og EUROP flokka sem metnir voru bæði rafrænt (VIAscan®) (n=18.680) og af matsmönnum í sláturhúsi ( $\mathrm{n}=26.795)$ var metið ásamt erfða- og svipfarsfylgni pessara eiginleika við mælingar og dóma á lifandi lömbum ( $\mathrm{n}=9.930$ ), (ómmælingar, stig fyrir frampart og læri ásamt legglengd). Erfðafylgni milli EUROP flokkunar matsmanna og VIAscan ${ }^{\circledR}$ flokkunar var 0,94 fyrir holdfyllingu og 0,82 
fyrir fitu. Arfgengi holdfyllingarmats var 0,32 fyrir VIAscan ${ }^{\circledR}$ og 0,35 fyrir sláturhúsmat og arfgengi stiga fyrir fitu var 0,29 og 0,31. Arfgengi nýtingar (LMY) metin með VIAscan® sem kg nýtanlegt kjöt í hverjum skrokkhluta (frampartur, hryggur, læri) var 0,17-0,21 metið sem bein áhrif, 0,09-0,11 metið sem erfðaáhrif mæðra og sameiginleg umhverfisáhrif frá móður voru metin 0,22-0,23. Vöðvahlutfall í heilum skrokk (LMY_\%) hafði hæsta erfðafylgni við lærastig $(0,44)$ af eiginleikum lifandi lamba og fylgni nýtingar í premur skrokkhlutum (læri, hryggur, frampartur) við mat á lifandi lömbum var lág til meðalhá og hagstæð nema fyrir hrygg. Niðurstöður beggja aðferða við EUROP mat á skrokkum höfðu sambærilega erfða- og svipfarsfylgni við mat á lifandi lömbum par sem holdfyllingarflokkar höfðu hæsta fylgni við lærastig, frampartsstig og ómælingu á vöðva en fituflokkar voru jákvætt tengdir frampartsstigum og ómmælingu á fitu. Niðurstöður gefa til kynna að rafrænt kjötmat með VIAscan ${ }^{\circledR}$ sé nothæf aðferð við íslenskar aðstæður og að mælingar sem matið skilar megi nýta í kynbótastarfi í sauðfjárrækt.

\section{INTRODUCTION}

Generally the objectives of carcass grading are to evaluate the carcass composition, ensure fair payment to farmers, classify the product for further processing and provide information to breeders. The method has to be accurate and precise over time and distance and crucial properties are the cost and speed of the method (Stanford et al. 1998, Johansen et al. 2006). The current lamb carcass grading in Iceland is based on the EUROP classification system (Johansen et al. 2006) where carcasses are classified according to the conformation and external fatness by trained operators (Reglugerð um gæðamat, flokkun og merkingu sláturafurða nr. 882/2010). Information on carcass weight and grading is traced back to individual animals' identification tags at the abattoirs and is electronically transferred to the recording system and used directly for breeding value estimation. Ultrasonic measurements and visual conformation scores on live lambs (here called in vivo traits) are widely used among farmers to select breeding animals. Experiments with objective carcass grading started in 2006 in Iceland using the Australian video image analysis system VIAscan ${ }^{\circledR}$ to predict lean meat yield and EUROP scores (Hopkins et al. 2004).

Veerkamp et al. (2002) showed how genetic parameters can be used to test different classifiers to ensure that they rank animals consistently and in agreement with each other. Genetic parameters of lamb carcass composition obtained by VIA technology have been published in a few studies (Jopson et al.
2009, Payne et al. 2009, Rius-Viarrasa et al. 2009). There are, however, no published values of genetic parameters for EUROP lamb carcass traits based on the VIA technology, to our best knowledge. Similarly genetic correlations of VIA-based EUROP scores and carcass yield predictions with the in vivo traits presented here have not been published before.

The objectives of this study were to estimate and compare the heritability of carcass traits based on the VIAscan ${ }^{\circledR}$ assessment, the current lamb carcass grading system and in vivo measurements of conformation and ultrasonic tissue depth, as well as estimating the genetic correlations between all these traits. The main objective was to evaluate the ability of VIAscan ${ }^{\circledR}$ as a grading tool for lamb carcasses and to seek answers to the following research questions:

- Can the EUROP scores based on VIAscan ${ }^{\circledR}$ and EUROP scores based on the current grading system be considered as equivalent for selection purposes with comparable heritability and comparable genetic correlations with in vivo traits?

- How heritable are the VIAscan ${ }^{\circledR}$ estimates of lean meat yield and how are they genetically correlated with the in vivo traits?

\section{MATERIAL AND METHODS}

\section{Animals}

The data set contained records for carcass traits based on VIAscan ${ }^{\circledR}$ predictions, abattoir assessments and in vivo ultrasonic measurements and conformation scores. Data were collected 
from 48 commercial sheep breeding farms in 2007 and 2008. All farms participated in a progeny testing program involving live judgement of lambs and recording of carcass traits. All flocks were registered in the national sheep recording system. Individual ID tags of all lambs were recorded before entering the slaughter line and linked to the running number of the carcass in the computer system at the abattoir. The weight and grade of each carcass were recorded at the end of the line and thus connected automatically to the animal ID.

\section{Carcass traits}

EUROP scores and yield predictions based on the video image analysis by the VIAscan ${ }^{\circledR}$ equipment are designated as VIAscan ${ }^{\circledR}$ traits. Briefly, the VIA technique provides automatic measurements on a digital image of each carcass as it passes through a camera chamber placed near the end of the slaughter line. EUROP scores and lean yield are subsequently estimated using prediction equations based on selected measurements. A more detailed description of the VIAscan ${ }^{\circledR}$ unit is given by Einarsson et al. (2014). The VIAscan ${ }^{\circledR}$ equipment predicts total lean meat yield in the carcass, specifically for leg, loin and shoulders, presented both as percentage and weight.

All carcasses were graded at slaughter according to national Icelandic regulations (Reglugerð um gæðamat, flokkun og merkingu sláturafurða nr. 882/2010) into five conformation classes; E, U, R, O, P and six fat classes; 1, 2, 3, 3+, 4, 5. The EUROP scores were transformed to numerical scores according to the original 15 point scale (Johansen et al. 2006) as follows: conformation classes $E=14$, $\mathrm{U}=11, \mathrm{R}=8, \mathrm{O}=5, \mathrm{P}=2$; fat classes: $1=2,2=5$, $3=8,3+=9,4=11,5=14$. The fat class is based on tissue depth measured above the 12th rib, $11 \mathrm{~cm}$ from midline, recognized as the GR measurement (Stanford et al., 1998). The GR is measured manually with a digital probe at

Table 1. Trait descriptions, number of records $(\mathrm{N})$, means, standard deviations (SD) and ranges for all traits included in the analysis.

\begin{tabular}{|c|c|c|c|c|c|c|}
\hline Traits & Trait description & $\mathbf{N}$ & Mean & SD & Min. & Max. \\
\hline \multicolumn{7}{|c|}{ VIAscan ${ }^{\circledR}$ traits } \\
\hline viaEUROPc & VIA estimate of EUROP conformation score (2 -14) & 18,745 & 8.46 & 2.02 & 2.0 & 14.0 \\
\hline viaEUROPf & VIA estimate of EUROP fat score (2 -14) & 18,745 & 6.84 & 1.98 & 2.0 & 14.0 \\
\hline LMY_\% & VIA estimated lean meat yield (\%) & 18,745 & 61.37 & 1.79 & 48.60 & 73.63 \\
\hline LegY_\% & VIA estimated lean meat yield in legs (\%) & 18,745 & 23.72 & 1.03 & 18.80 & 37.50 \\
\hline LoinY_̄o & VIA estimated lean meat yield in loin (\%) & 18,745 & 15.84 & 0.64 & 13.00 & 18.10 \\
\hline ShldrY_\% & VIA estimated lean meat yield in shoulders (\%) & 18,745 & 21.81 & 1.04 & 13.40 & 26.10 \\
\hline Leg_kg & VIA estimated weight of lean in legs $(\mathrm{kg})$ & 18,680 & 3.6 & 0.54 & 1.69 & 6.44 \\
\hline Loin_kg & VIA estimated weight of lean meat in loin $(\mathrm{kg})$ & 18,680 & 2.5 & 0.45 & 0.99 & 4.82 \\
\hline Shldr_kg & VIA estimated weight of lean meat in shoulders $(\mathrm{kg})$ & 18,680 & 3.4 & 0.56 & 1.47 & 5.90 \\
\hline \multicolumn{7}{|c|}{ Abattoir traits } \\
\hline pEUROPc & Visual EUROP conformation score (2 -14) & 33,414 & 8.74 & 1.83 & 2.0 & 14.0 \\
\hline pEUROPf & Visual EUROP fat score $(2-14)$ & 33,414 & 6.87 & 1.77 & 2.0 & 14.0 \\
\hline GR & $\begin{array}{l}\text { Fat depth at } 12 \text { th rib, } 11 \mathrm{~cm} \text { from carcass midline } \\
(\mathrm{mm})\end{array}$ & 26,975 & 8.64 & 2.11 & 2.0 & 18.4 \\
\hline $\mathrm{CCW}$ & Cold carcass weight $(\mathrm{kg})$ & 33,185 & 15.60 & 2.55 & 6.7 & 29.7 \\
\hline \multicolumn{7}{|l|}{ In vivo traits } \\
\hline UMD & Ultrasound muscle depth in vivo at $3^{\text {rd }}$ lumbar ( $\left.\mathrm{mm}\right)$ & 10,091 & 26.03 & 2.82 & 16.0 & 38.0 \\
\hline UFD & Ultrasound fat depth in vivo at $3^{\text {rd }}$ lumbar (mm) & 9,992 & 2.95 & 0.95 & 0.7 & 9.0 \\
\hline UMS & Score for the ultrasound muscle shape $(1-5)$ & 9,992 & 3.60 & 0.53 & 1.5 & 5.0 \\
\hline Shldr_score & Shoulder and breast conformation score $(5-10)$ & 9,978 & 8.18 & 0.39 & 7.0 & 9.5 \\
\hline Leg_score & Conformation score of hind legs $(10-20)$ & 9,978 & 16.88 & 0.54 & 15.0 & 19.5 \\
\hline ML & Length of the left metacarpal (cannon bone) (mm) & 4,364 & 109.0 & 4.20 & 95 & 125 \\
\hline LW & Live weight $(\mathrm{kg})$ & 10,043 & 40.8 & 5.10 & 22.0 & 67.0 \\
\hline
\end{tabular}


the grading point and each fat score represents a defined range of GR values. Carcass grading at the abattoir was carried out by the same two experienced graders in both years. Hot carcass weight $(\mathrm{HCW})$ was obtained at the end of the slaughter line and cold carcass weight $(\mathrm{CCW}=$ HCW x 0,978 ) was calculated automatically and recorded for each carcass. The EUROP scores, GR and CCW are designated as abattoir traits.

\section{In vivo traits}

The in vivo traits were obtained by trained judges, in most cases within two weeks before slaughter. Ultrasonic muscle depth (UMD) was measured at the third lumbar vertebrae where the eye-muscle (m. longissimus lumborum) is deepest. Fat depth (UFD) was measured directly above the UMD. The ultrasonic muscle shape (UMS) is a visual score from 1 to 5 , where the highest score describes a thick and broad muscle shape. All lambs were scored for conformation of legs (Leg_score, 15-20) and shoulders (Shldr score, 5-10). The length of the left metacarpal (cannon) bone (ML) was measured with a ruler on ram lambs only. Table 1 shows descriptive statistics for all 20 traits that were included in the analysis.

\section{Data structure}

Performance records for at least one group of traits were available for 38,576 lambs in total, including both ewe lambs and entire ram lambs, where 1,446 lambs had records for all 20 traits. The structure of the data set is shown in Table 2 according to trait groups. VIAscan ${ }^{\circledR}$ records with error codes were excluded from the data analysis. Of the 26,795 lambs with information on all abattoir traits, 20,933 were slaughtered at the KS abattoir holding the VIAscan unit.
The lambs were sired by 885 rams with the average progeny group of 42 lambs, ranging from 1 to 287 offspring. Common sires of lambs with records in all trait groups were 758 while 814 sires had lambs with records on VIA traits and abattoir traits. Dams of lambs with records numbered 18,577 and there were 12,705 dams with records on two or more lambs. The average age of lambs at slaughter was 135 days. The majority of lambs were born as twins $(75 \%)$ and reared as twins. Lambs reared as quadruplets or more were excluded. Relative numbers of ram lambs and ewe lambs differ markedly between trait groups as in vivo traits were mainly measured on candidates for selection.

\section{Statistical analysis}

Analysis of fixed effects for all traits was carried out using the SAS-GLM procedure (SAS Institute Inc. 2004. SAS OnlineDoc ${ }^{\circledR}$ 9.1.3. Cary, NC: SAS Institute Inc.). The fixed effects included in the models were a combination of flock and year, sex (male or female), age class of dam $(1,2,3-5,6+)$, type of rearing (single, twin, triplet). The linear covariates included were cold carcass weight (CCW) for EUROP scores and GR; live weight (LW) for in vivo traits and birth date deviation (days counted from April $1^{\text {st }}$ ) for weight related traits. Other fixed effects and covariates tested were of less importance and were not included in the final models (type of birth, age at slaughter, abattoir, date of slaughter, CCW quadratic, type of ultrasound unit and interactions).

Three different animal models were used to estimate the (co)variance components (Table 3 ). Maternal genetic effects were only included in the model (3) for weight related traits only while the models used for other carcass traits included

Table 2. Data structure.

\begin{tabular}{lccc}
\hline & VIAscan ${ }^{\circledR}$ traits & Abattoir traits & ${\text { In vivo } \text { traits }^{\mathbf{a}}}$ \\
\hline Lambs with records & 18.680 & 26.795 & 9.930 \\
Sires (n) & 815 & 845 & 821 \\
Dams (n) & 12.073 & 15.125 & 7.189 \\
Males:females & $10,405: 8,275$ & $15,048: 11,747$ & $1,419: 8,511$ \\
Flock-years & 68 & 69 & 68 \\
\hline
\end{tabular}

${ }^{a}$ ML not included. 
a linear regression on weight which included the maternal effects. The models were as follows:

$$
\begin{aligned}
& \mathrm{Y}_{\mathrm{ijkm}}=\mathrm{f}_{\mathrm{i}}+\mathrm{s}_{\mathrm{j}}+\mathrm{d}_{\mathrm{k}}+\mathrm{b}_{1}\left(\mathrm{CCW}_{\mathrm{ijkm}}\right)+\mathrm{a}_{\mathrm{m}}+\mathrm{e}_{\mathrm{ijkm}} \\
& Y_{i j k m}=f_{i}+s_{j}+d_{k}+b_{2}\left(L W_{i j k m}\right)+a_{m}+e_{i j k m} \\
& \begin{array}{l}
Y_{i j k l m n o}=f_{i}+s_{j}+d_{k}+n_{l}+b_{3}\left(\text { birth_dev }_{i j k k m n o}\right)+ \\
a_{m}+m_{n}+c_{o}+e_{i j k l m n o}
\end{array}
\end{aligned}
$$

where;

$Y$ indicates the record for animal $\mathrm{m}$,

$f_{i}$ is the effect of $\mathrm{i}^{\text {th }}$ combination of year and farm,

$s_{j}$ is the effect of $\mathrm{j}^{\text {th }}$ sex of animal,

$d_{k}$ is the effect of $\mathrm{k}^{\text {th }}$ dam age,

$n_{l}$ is the effect of $\mathrm{l}^{\text {th }}$ type of rearing,

$b 1(C C W)$ is the linear regression coefficient of $\mathrm{Y}$ on carcass weight,

$b 2(L W)$ is the linear regression coefficient of $\mathrm{Y}$ on live weight,

b3(birth_dev) is the linear regression coefficient of $\mathrm{Y}$ on birth date,deviation,

$a_{m}$ is the direct additive genetic effect of the $\mathrm{m}^{\text {th }}$ animal, $a_{m}$ $\sim N\left(0, \sigma_{a}^{2}\right)$,

$m_{n}$ is the maternal additive genetic effect of the $\mathrm{n}^{\text {th }}$ dam, $m_{n}$ $\sim N\left(0, \sigma_{m}^{2}\right)$,

$c_{o}$ is the common environmental effect due to the $\mathrm{o}^{\text {th }}$ dam, $c_{o} \sim N\left(0, \sigma_{c}^{2}\right)$,

$e$ is random residual effect pertaining to the corresponding, $e \sim N\left(0, \sigma_{e}^{2}\right.$.

Table 3. Traits analysed by each of the three statistical models used to estimate (co)variance components (see Table 1 for trait descriptions)

\begin{tabular}{lll}
\hline Model 1 & Model 2 & Model 3 \\
\hline viaEUROPc & UMD & Leg_kg \\
viaEUROPf & UFD & Loin_kg \\
LMY_\% & UMS & Shldr_kg \\
LegY_\% & Shldr_score & CCW \\
LoinY_\% & Leg_score & LW \\
ShldrY_\% & ML & \\
pEUROPc & & \\
pEUROPf & & \\
GR & & \\
\hline
\end{tabular}

Variance components were estimated using Animal Model with REML, available in the DMU program-package (Madsen \& Jensen
2008). Heritability was estimated by single-trait analyses but genetic and phenotypic correlations were estimated in bivariate analyses. Heritability $\left(\mathrm{h}^{2}\right)$ based on models 1 and 2 was estimated as $h^{2}=\sigma_{a}^{2} / \sigma_{p}^{2}$ where $\sigma_{p}^{2}=\sigma_{a}^{2}+\sigma_{e \text {. }}^{2}$ In model 3 direct heritability was estimated as $h^{2}{ }_{d}=\sigma^{2}{ }_{a}$ / $\sigma_{p}^{2}$, maternal heritability as $h_{m}^{2}=\sigma_{m}^{2} / \sigma_{p}^{2}$ and common environment due to the dam as $c^{2}{ }_{c}=$ $\sigma_{c}^{2} / \sigma_{p}^{2}$ where $\sigma_{p}^{2}=\sigma_{a}^{2}+\sigma_{m}^{2}+\sigma_{a m}+\sigma_{c}^{2}+\sigma^{c}{ }_{e}$.

\section{RESULTS}

\section{Heritability and variation}

The estimates of heritability were moderate to high for all traits, ranging from 0.27 to 0.63 (Table 4). Heritability estimates for EUROP scores for conformation and fat predicted by VIAscan ${ }^{\circledR}$ were similar to those for visual scores. Heritability of VIAscan ${ }^{\circledR}$ traits based on lean yield percentages was high, ranging from 0.39 to 0.63 . Heritability of in vivo traits was lowest for the visual score of ultrasonic eye muscle shape (0.27) and highest for the length of the cannon bone $(0.52)$. The leg score had the highest heritability estimate $(0.40)$ of all visually estimated traits.

Variance components and heritability of weight-related traits are presented in Table 5. Direct heritability ranged from 0.17 to 0.22 , highest for LW. Maternal heritability ranged from 0.09 to 0.11 . Common environmental variance as a fraction of the total phenotypic variance was similar for all the traits, ranging between 0.21 and 0.23 . The direct-maternal genetic correlation was negative for all weightrelated traits, ranging from -0.25 to -0.35 .

The coefficient of additive genetic variation was highest for UFD (0.172) but lowest for Leg score (0.017) and ranged from 0.094 to 0.129 for EUROP score and GR (Table 4). VIAscan ${ }^{\circledR}$ yield traits showed lower variation, ranging from 0.019 to 0.027 . Ultrasonic traits showed rather large variation while the in vivo conformation scores and ML showed low variation.

\section{Genetic correlations}

The genetic correlation (Table 4) between conformation scores (viaEUROPc and pEUROPc) was high (0.94), while the genetic 

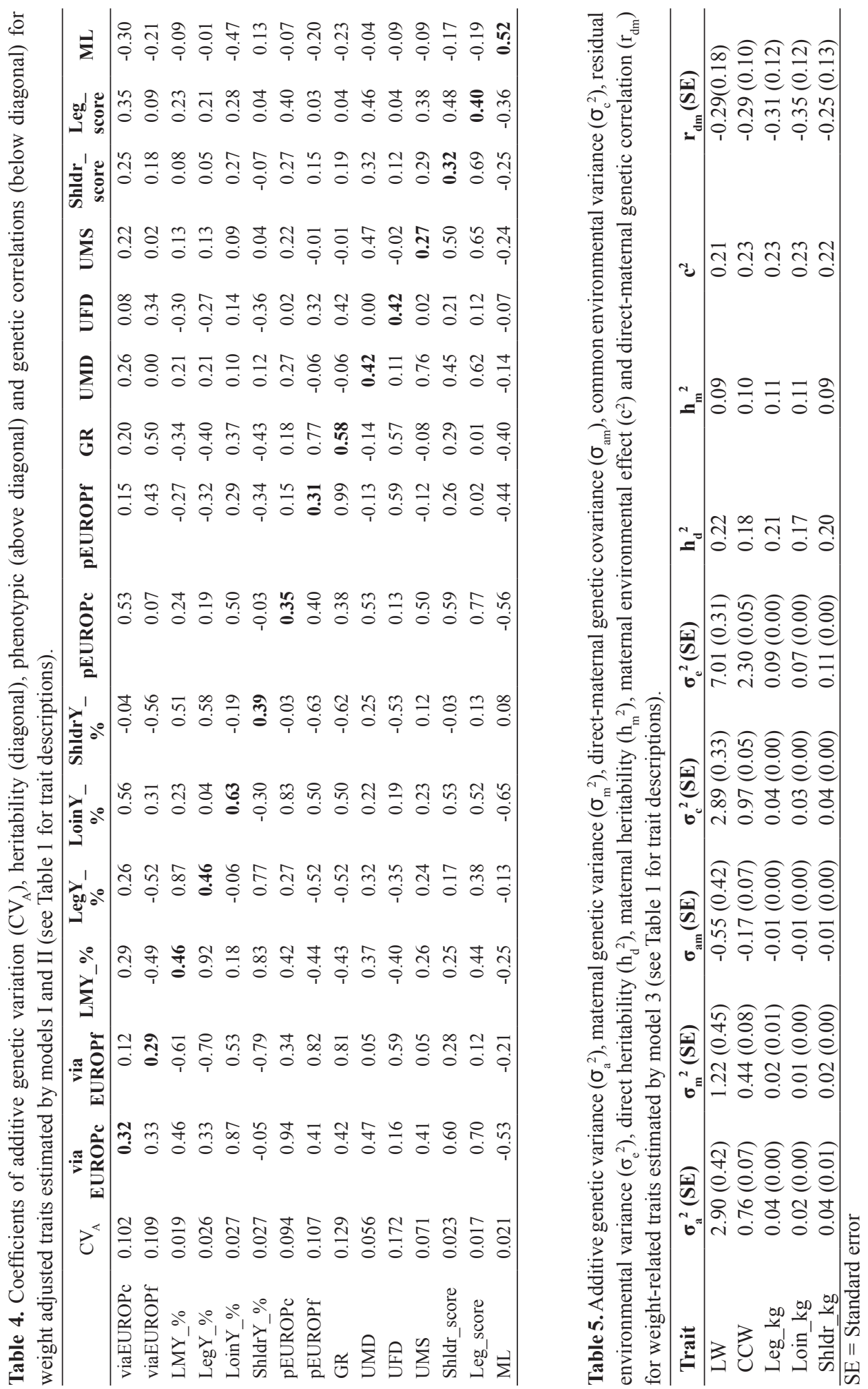
correlation between EUROP fat scores was slightly lower (0.82). The genetic correlations between the in vivo traits and EUROP scores were similar for both grading methods. Leg score had high genetic correlations with EUROP conformation scores (both methods) while the correlation of UMD with EUROP conformation scores was lower. UFD was genetically highly correlated with EUROP fat scores (0.59) obtained by both methods. The LMY_\% had the highest genetic correlations with Leg score (0.44) and UFD (-0.40) of the in vivo traits. The LMY_\% had higher correlations with the EUROP scores based on VIAscan ${ }^{\circledR}$ than with the scores given by abattoir assessors. LegY_\% and ShldrY_\% were highly positively correlated with each other but negatively correlated with LoinY_\%. LoinY_\% was positively correlated with EUROP fat score, GR and UFD, opposite to LegY_\% and ShldrY_\%, as well as highly correlated with both EUROP conformation scores. ShldrY_\% had almost no genetic correlation with the Shldr_score and was the only trait with a positive correlation with ML. LegY_\% had a weak positive genetic correlation with Shldr_score, but a negative correlation with ML and rather strong positive correlation with Leg_score.

All weight-related traits were highly intercorrelated, especially VIAscan ${ }^{\circledR}$ yield traits and CCW (results not shown).

\section{DISCUSSION}

\section{Heritability}

Heritability estimates of EUROP scores evaluated either by VIAscan ${ }^{\circledR}$ or abattoir assessors were similar, ranging from 0.29 to 0.35 , indicating the comparable accuracy of both methods. Equivalent breeding progress may thus be expected from selection based on both methods. Heritability estimates of EUROP conformation scores in the current study were somewhat lower than found in an earlier study (0.40) of Icelandic sheep (Sævarsson 1999). Conington et al. (1998), Näsholm (2004), Karamichou et al. (2007) \& Rius-Vilarrasa et al. (2010) reported heritability estimates from 0.09 to 0.29 for carcass conformation score.
Maxa et al. (2007) obtained higher heritability estimates of 0.35-0.45 for carcass conformation of Shropshire and Texel sheep, respectively, a finding comparable to the current results. Heritability of fat score was slightly higher than the previous estimate $(0.27)$ reported by Sævarsson (1999). Näsholm (2004) estimated the heritability of fat score ranging from 0.25 to 0.29 , which agrees with the current study, but Conington et al. (1998), Karamichou et al. (2007), Maxa et al. (2007) and Rius-Vilarrasa et al. (2010) found lower estimates ranging from 0.10 to 0.19 . The heritability estimate of GR was much higher than for the EUROP fat score. This difference may have been caused by a scale effect, since GR is measured on a continuous linear scale which is more precise than the EUROP score although based directly on the GR. Thorsteinsson (2002) estimated heritability of fat depth over the 12th rib (J-measurement) as 0.52 , in agreement with the current study but other heritability estimates of this trait cover a wide range $(0.28-0.70)$ (Eythórsdóttir 2012). Estimates of heritability of carcass yield as a percentage of weight in the literature are often high. Stanford et al. (1998) reviewed methods of predicting lamb carcass composition where they concluded that heritability for this trait would commonly range from 0.40 to 0.45 . No heritability estimates were found in the literature for a VIA prediction of yield percentage. Payne et al. (2009) estimated genetic parameters for VIAscan ${ }^{\circledR}$ traits where lean weight, adjusted for carcass weight, showed lower heritability estimates than in the current study, ranging from 0.18 to 0.25 . The heritability estimates for UMD and UFD reported here are exactly the same as Thorsteinsson \& Eythórsdóttir (1998) found in an earlier study on Icelandic lambs (0.42). These estimates are rather high, although within the range of previous findings. Puntila et al. (2002), Simm et al. (2002), Roden et al. (2003) reported heritability estimates of $0.39-0.56$ and 0.26-0.46 for UMD and UFD, respectively. UMS had a lower heritability than both UMD and UFD, which is probably because the UMS is visually evaluated with lower accuracy and is difficult to standardize. This study is, to the best 
of our knowledge, the first published heritability estimates for a visual score of the shape of the eye-muscle. Jones et al. (2004) used measures of muscularity based on CT measurements of eyemuscle dimensions and obtained heritability estimates ranging from 0.22 to 0.57 in three breeds. Leg score had higher heritability than other visual conformation scores in this study, even though this trait had a narrow genetic distribution $\left(C V_{A}:\right.$ 0.017). High heritability estimates of in vivo conformation score of the hind limb have been reported, ranging from 0.31 to 0.62 (Thorsteinsson \& Björnsson 1982, Janssens \& Vandepitte 2004, Wolf \& Jones 2007). ML was found to be highly heritable (0.52) in accordance with other studies that have reported extremely high heritability estimates for this trait, ranging from 0.64 to 0.82 (Thorsteinsson \& Björnsson 1982, Bennett et al. 1991).

\section{Direct and maternal heritability of weight related traits}

Direct heritabilities of weight related traits (LW, CCW, Leg_kg, Loin_kg, Shldr_kg) were generally in good agreement with previous findings. Safari et al. (2005) presented a weighted mean of 0.20 for heritability of carcass weight and Simm (2000) suggested a typical heritability for weaning weight of 0.15 to 0.25 . Heritability estimates for carcass weight and weaning weight of Icelandic lambs were reviewed by Eythórsdóttir (2012) and ranged from 0.11 to 0.18 and 0.15 to 0.24 , respectively. The heritability estimates for prediction of lean weight in the current study was similar to that found by Rius-Viarrasa et al. (2009) for leg $(0.20)$ and loin weight $(0.26)$ but they reported lower values for shoulder weight (0.08) based on VIA predictions of lamb carcasses in the UK. Jopson et al. (2009) found somewhat higher estimates for these traits, ranging from 0.37 to 0.42 based on VIAscan ${ }^{\circledR}$ evaluations in New Zealand.

The presence of maternal effects on weight related traits in sheep is well known and has been reported by many authors (Safari et al. 2005). Results for direct heritability, maternal heritability and common environmental effects for LW agree with the findings of Wolf and Jones (2007). The maternal heritability also agreed with values reported by Näsholm (2004) but common environmental effects were stronger in the current study. Eythórsdóttir (1999) estimated the effects of common environment on carcass weight as 0.27 for Icelandic lambs and Jónmundsson (1976) reported maternal heritability of autumn weight of 0.27 while effects of common environment were not estimated. Strong common environmental effects can be expected under the Icelandic production system, where the lambs go with their mothers on mountain pastures through most of the growing period in variable environments. Negative correlations between direct and maternal genetic effects for weight related traits as reported here have been widely reported and reviewed (Safari et al. 2005).

\section{Correlations}

The high genetic correlation (0.94) between viaEUROPc and pEUROPc indicates that VIAscan ${ }^{\circledR}$ and the graders at the abattoir are evaluating the same trait. The genetic correlation was not as strong $(0.82)$ between viaEUROPf and pEUROPf. A lower limit of 0.70 for genetic correlation between interchangeable traits has been used in practice by Interbull (2001). Using this as a guideline one can argue that EUROP scores obtained by VIAscan ${ }^{\circledR}$ are sufficiently close to the current grading system to be considered interchangeable in the breeding program and that both methods could be used simultaneously. The fat score from VIAscan ${ }^{\circledR}$ is based on estimated fat cover in a dorsal view of the carcass while the classifiers use the GR measure as a major guideline for the fat score. Studies have shown that fat measurements on various parts on the carcass, although highly correlated, cannot be treated as one trait. Bennett et al. (1991) found a high genetic correlation (0.83) between measurements of fat thickness on the back (C) and on the rib (J); similarly Thorsteinsson and Björnsson (1982) also reported a high correlation (0.62). The genetic correlation of 0.99 found here between 
GR and pEUROPf indicates that the GR fat measurement totally controls the EUROP fat score given by the abattoir graders. Selection for low fat score based on pEUROPf can thus be expected to decrease fat on the side, while selection based on a fat score from VIAscan ${ }^{\circledR}$ could be expected to decrease fat on the dorsal area of the carcass. Using the VIAscan ${ }^{\circledR}$ fat score based on six patches along the dorsal view as selection criteria might also be better suited to control the carcass fat distribution than the single GR measure. Given the high heritability of GR and the close relationship between GR and the currently used pEUROPf it would be advisable to use the GR measurement directly in the breeding work.

A high positive genetic correlation was found between the EUROP conformation score and fat score, indicating that selection for improved conformation will increase fatness. This unfavourable correlation was stronger between the assessments given by the graders than the VIAscan ${ }^{\circledR}$, which may have been due to the poorer ability of the VIAscan ${ }^{\circledR}$ to estimate fat score that was evident in a previous report by Einarsson et al. (2014). Studies on beef carcasses have shown that the VIA technique has not been able to predict the fat score with the same accuracy as the conformation score (Craigie et al. 2012). Positive genetic correlations between conformation and fat have been found in several other studies (Safari et al. 2005, Karamichou et al. 2007).

The yield proportion estimates, with the exception of LoinY_\%, had stronger correlations with the EUROP fat score than the conformation score, which is in agreement with Johansen et al. (2006). LoinY\% was negatively correlated with LegY_\% and ShldrY_\% while LegY_\% and ShldrY_\% were highly positively correlated. This was unexpected and opposite to the results of Payne et al. (2009). Furthermore LoinY_\% was more closely related to the EUROP fat score, GR and UFD than to LMY_\%. The methodology used to obtain the boning data from which the yield equations were derived might explain this controversy as the flanks were not dissected into fat and lean and were included with the lean meat yield in loin (Einarsson et al. 2014). This resulted in inaccurate lean meat yield predictions of the loin that makes it difficult to infer the relationship of LoinY_\% and LMY_\% with other traits. For future development of the loin yield equation this needs to be corrected. Possible methods are to exclude the flanks or correct them for fatness, either according to GR or by chemical methods, as described by Hopkins et al. (2004).

Most in vivo traits had favourable genetic correlations with LegY_\% and ShldrY_\% and selection for these traits can be expected to improve VIAscan ${ }^{\circledR}$ yield traits. The EUROP scores from VIAscan ${ }^{\circledR}$ had, in general, similar correlations with the in vivo traits as the visual EUROP scores. The usefulness of UMD and UFD as predictors for carcass yield is well known from the literature (Stanford et al. 1998) and was confirmed here. The genetic correlation between UMD and both EUROP conformation scores was rather high compared to Karamichou et al. (2007), while others have found similar or higher genetic correlations between these traits (Maxa et al. 2007). The genetic correlation between UFD and the EUROP fat score was much lower than Karamichou et al. (2007) found (0.97), while Maxa et al. (2007) obtained a similar estimate (0.66) for Shropshire in Denmark. The positive genetic correlation between UMD and UFD is in agreement with other studies (Safari et al. 2005, Puntila et al. 2002) although negative correlations can also be found between these traits in the literature (Conington et al. 1995, Maxa et al. 2007, Thorsteinsson \& Eythórsdóttir 1998). These first results of genetic parameters for UMS show that this trait is highly correlated with UMD but has a similar or weaker relation to all abattoir and VIAscan ${ }^{\circledR}$ traits than UMD. The usefulness of UMS as a selection trait for improved lean meat yield and conformation should thus be further analysed. The Leg_score is the most important indicator trait for the EUROP conformation score according to the genetic correlation. The leg score had a positive genetic correlation with LegY_\%, while there was almost no genetic correlation between shoulder score and 
ShldrY_\%. It seems likely that live lamb judges tend to give fat lambs relatively high scores for shoulders that do not reflect the actual lean meat yield.

\section{CONCLUSION}

The current grading system of lamb carcasses based on visual carcass assessment can be replaced by the VIAscan ${ }^{\circledR}$ technique since genetic correlations between objective and subjective EUROP assessments are sufficiently strong and the heritability is comparable between methods. A stronger genetic correlation between the fat scores is to be desired, especially if information based on both methods is used simultaneously for breeding purposes. Future use of the VIAscan ${ }^{\circledR}$ yield predictions requires revision of the equation for lean in the loin by either excluding the flank from the loin yield or correcting it for fatness using total carcass fatness measured during the boning trials. Automatic carcass grading has the advantage of consistency between abattoirs and over time that is difficult to achieve with human scoring, and the supposed lack of consistency between abattoirs has been a repeated subject of discussion among sheep farmers. The VIAscan ${ }^{\circledR}$ technique provides an option of standardized carcass grading for the Icelandic lamb industry by installing the technique in all the main abattoirs and offers the possibility of estimating carcass composition by yield predictions. These estimates are highly heritable and can be improved by selection for the in vivo traits that are currently in use. The costs of such a system change were not estimated in the current study and have to be evaluated against the opportunities created.

\section{ACKNOWLEDGEMENTS}

Dr Elsa Albertsdóttir and Porvaldur Kristjánsson are gratefully acknowledged for valuable help with the statistical analysis. Financial support was provided by the Memorial Fund of Dr Halldór Pálsson, The Agricultural Productivity Fund, The Sheep Farmers Association of Iceland and Hagsmunasamtök héraðsráðunauta (Association of Advisers in Agriculture).

\section{REFERENCES}

Bennett GL, Johnson DL, Kirton AH \& Carter AH 1991. Genetic and environmental effects on carcass characteristics of Southdown x Romney lambs: II. Genetic and phenotypic variation. Journal of Animal Science 69, 1864-1874.

Conington J, Bishop SC, Waterhouse A \& Simm G 1995. A genetic analysis of early growth and ultrasonic measurements in hill sheep. Animal Science 61, 85-93. doi: http://dx.doi.org/10.1017/ S1357729800013552

Conington J, Bishop SC, Waterhouse A \& Simm G 1998. A comparison of growth and carcass traits in Scottish Blackface lambs sired by genetically lean or fat rams. Animal Science 67, 299-309. doi: http://dx.doi.org/10.1017/S1357729800010067

Craigie CR, Navajas EA, Purchas RW, Maltin CA, Bünger L, Hoskin SO, Ross DW, Morris ST \& Roehe R 2012. A review of the development and use of video image analysis (VIA) for beef carcass evaluation as an alternative to the current EUROP system and other subjective systems. Meat Science 92, 307-318. doi: http://dx.doi.org/10.1016/j. meatsci.2012.05.028

Einarsson E, Eythórsdóttir E, Smith CR \& Jónmundsson JV 2014. The ability of video image analysis (VIA) to predict lean meat yield and EUROP score of lamb carcasses. Animal 8, 1170-1177. doi: http://dx.doi.org/10.1017/ S1751731114000962

Eythórsdóttir E 2012. Growth and carcass characteristics of Icelandic lambs - A review. Icelandic Agricultural Science 25, 59-66.

Eythórsdóttir E 1999. Genetic variation in woolskin quality of Icelandic lambs. Livestock Production. Science 57, 113-126.

Falconer DS \& Mackay, TFC 1996. Introduction to Quantitative Genetics, $4^{\text {th }}$ edition. Longman, Essex, UK, 464 p.

Hopkins DL, Safari E, Thompson JM \& Smith CR 2004. Video image analysis in the Australian meat industry - Precision and accuracy of predicting lean meat yield in lamb carcasses. Meat Science 67, 269-274. doi: http://dx.doi.org/10.1016/j. meatsci.2003.10.015

Interbull 2001. Interbull guidelines for national \& international genetic evaluation systems in dairy cattle with focus on production traits. Retrieved 10 
June 2010 from http://www.icar.org/Documents/ Rules\%20and\%20regulations/Guidelines/ interbull\%20guidelines\%202001.pdf

Janssens S \& Vandepitte W 2004. Genetic parameters for body measurements and linear type traits in Belgian Bleu du Maine, Suffolk and Texel sheep. Small Ruminant Research 54, 13-24. doi: http:// dx.doi.org/10.1016/j.smallrumres.2003.10.008

Johansen J, Aastveit AH, Egelandsdal B, Kvaal K \& Røe M 2006. Validation of the EUROP system for lamb classification in Norway; Repeatability and accuracy of visual assessment and prediction of lamb carcass composition. Meat Science 74, 497-509. doi: http://dx.doi.org/10.1016/j. meatsci.2006.04.017

Jones HE, Lewis RM, Young MJ \& Simm G 2004. Genetic parameters for carcass composition and muscularity in sheep measured by X-ray computer tomography, ultrasound and dissection. Livestock Production Science 90, 167-179. doi: http://dx.doi. org/10.1016/j.livprodsci.2004.04.004

Jopson NB, McEwan JC, Logan CM \& Muir PD 2009. Genetic parameters for primal cut meat yield traits in sheep. Proceedings of the New Zealand Society of Animal Production 69, 215-219.

Jónmundsson JV 1976. Studies on autumn weight of Icelandic lambs. II. Heritability estimates. Journal of Agricultural Research in Iceland 8, 54-58.

Karamichou E, Merrell BG, Murray WA, Simm G \& Bishop SC 2007. Selection for carcass quality in hill sheep measured by X-ray computer tomography. Animal 1, 3-11. doi: http://dx.doi. org/10.1017/S1751731107413684

Madsen, $\mathbf{P}$ \& Jensen $\mathbf{J}$ 2008. A user's guide to $D M U$. A package for analysing multivariate mixed models. Version 6, release 4.7. Danish Institute of Agricultural Sciences, Research Centre Foulum, Denmark, $32 \mathrm{p}$.

Maxa J, Norberg E, Berg P \& Pedersen J 2007. Genetic parameters for carcass traits and in vivo measured muscle and fat depth in Danish Texel and Shropshire. Acta Agricultura Scandinavica Sect. A, 57, 49-54. doi: http://dx.doi.org/10.1080/0906 4700701440439

Näsholm A 2004. Direct and maternal genetic relationships of lamb live weight and carcass traits in Swedish sheep breeds. Journal of Animal Breeding and Genetics 121, 66-75. doi: http:// dx.doi.org/10.1046/j.1439-0388.2003.00440.x
Payne GM, Campbell AW, Jopson NB, McEwan JC, Logan, CM \& Muir PD 2009. Genetic and phenotypic parameter estimates for growth, yield and meat quality traits in lamb. Proceedings of the New Zealand Society of Animal Production 69, 210-214.

Puntila ML, Mäki K \& Rintala O 2002. Assessment of carcass composition based on ultrasonic measurements and EUROP conformation class of live lambs. Journal of Animal Breeding and Genetics 119, 367-378. doi: http://dx.doi. org/10.1046/j.1439-0388.2002.00358.x

Reglugerð um gæðamat, flokkun og merkingu sláturafurða nr. 882/2010 [Regulation on quality grading, classification and identification of slaughter products]. Sjávarútvegs- og landbúnaðarráðuneytið, Reykjavík. Accessed 10 August 2014 at: http://www.reglugerd.is/interpro/ $\mathrm{dkm} /$ WebGuard.nsf/58b439f05a7f412f00256a070 03476bc/8bda2b615f13a1ef002577e6004ad8c6?O penDocument. [In Icelandic].

Rius-Vilarrasa E, Bünger L, Brotherstone $\mathrm{S}$, Matthews KR, Haresign W, Macfarlane JM, Davies M \& Roehe R 2009. Genetic parameters for carcass composition and performance data in crossbred lambs measured by video image analysis. Meat Science 81, 619-625. doi: http:// dx.doi.org/10.1016/j.meatsci.2008.10.020

Rius-Vilarrasa E, Bünger L, Brotherstone, Macfarlane JM, Lambe NR, Matthews KR, Haresign W \& Roehe R 2010. Genetic parameters for carcass dimensional measurements from video image analysis and their association with conformation and fat class scores. Livestock Science 128, 92-100. doi: http://dx.doi.org/10.1016/j. livsci.2009.11.004

Roden JA, Merrell BG, Murray WA \& Haresign W 2003. Genetic analysis of live weight and ultrasonic fat and muscle traits in a hill sheep flock undergoing breed improvement utilizing an embryo transfer programme. Animal Science 76, 367-373.

Safari E, Fogarty NM \& Gilmour AR 2005. A review of genetic parameter estimates for wool, growth, meat and reproduction traits in sheep. Livestock Production Science 92, 271-289. doi: http://dx.doi.org/10.1016/j.livprodsci.2004.09.003 
Simm G 2000. Genetic Improvement of Cattle and Sheep. Farming Press, Tonbridge, UK, 433 p.

Simm G, Lewis RM, Grundy B \& Dingwall WS 2002. Responses to selection for lean growth in sheep. Animal Science 74, 39-50.

Stanford K, Jones SDM \& Price MA 1998. Methods of predicting lamb carcass composition: A review. Small Ruminant Research 29, 241-254.

Sævarsson SÓ 1999. Erfðastuðlar við mat á dilkakjöti, samanburður á nýju og eldra kjötmati. [Genetic parameters of lamb carcass classification - comparison of new and previous grading systems]. Unpublished B.Sc. thesis. Búvísindadeild Bændaskólans á Hvanneyri, 21 p. [In Icelandic].

Thorsteinsson SS 2002. Rannsóknir og kynbætur sauðfjár fyrir bættu vaxtarlagi og betri kjötgæðum [Research and breeding work in sheep for improved conformation and carcass quality]. Rádunautafundur 2002, 149-167. [In Icelandic].

Thorsteinsson SS \& Björnsson H 1982. Genetic studies on carcass traits in Iceland twin ram lambs I. Livestock Production Science 8, 489-505.

Thorsteinsson SS \& Eythórsdóttir E 1998. Genetic parameters of ultrasonic and carcass cross-sectional measurements and muscle and fat weight of Icelandic lambs. Proceedings of the $6^{\text {th }}$ World Congress on Genetics Applied to Livestock Production, Armidale, NSW, Australia, January 11-16, 1998, 24, 149-152.

Veerkamp RF, Gerritsen CLM, Koenen EPC, Hamoen A \& De Jong G 2002. Evaluation of classifiers that score linear type traits and body condition score using common sires. Journal of Dairy Science 85, 976-983. doi: http://dx.doi. org/10.3168/jds.S0022-0302(02)74157-X

Wolf BT \& Jones DA 2007. Inheritance of an in vivo leg conformation score in Texel lambs and its association with growth, ultrasonic measurements and muscularity. Livestock Science 110, 133-140. doi: http://dx.doi.org/10.1016/j.livsci.2006.10.012

Manuscript received 27 March 2014 Accepted 14 October 2014 